\title{
Indigenisation and Africanisation of Legal Education: Advantaging Legal Pluralism in South Africa
}

\section{Fayth Ruffin}

\section{Abstract}

This conceptual paper navigates a way to 'indigenise' law school curriculum to disrupt the centralist legal mind and advance access to justice for all. Literature insufficiently shows how to design and implement curriculum and assessment practice in the decolonisation project. Innovatively drawing upon South African legal pluralism to highlight curriculum development beyond borders, the paper distinguishes decolonisation, indigenisation and Africanisation and shows their interactivity through the gaze of African ontoepistemologies, axiologies and cosmologies. Through discourse analysis, interpretivism and experientialism grounding, I argue that failure to Africanise legal education perpetuates a justice deficit in breach of the South African Constitution. The paper concludes that hegemonic privileging of rule of law orthodoxy diminishes usefulness of both non-state community-based justice systems and customary justice systems despite widespread use of the latter two systems. Recommendations include use of 'cultural interface' and 'critical standpoints' (Nakata 2007: 7; Carey \& Prince 2010: 207) to generate inclusive strategic law school curriculum development. Assessment practice should involve socio-legal research through indigenous methodologies with findings used to advance epistemic freedom in a transdisciplinary way to spur further curriculum transformation. This can facilitate professional development opportunities for judges and lawyers to allow living African law to develop within its socio-cultural environment and the Bill of Rights.

Keywords: African epistemologies, African indigenous knowledge systems, Africanisation of legal education, cognitive imperialism, decolonisation of legal education, epistemic freedom, legal pluralism. 


\section{Introduction}

Law school curriculum tends to reaffirm cognitive imperialism (Battiste 2017). This is problematic because law school graduates are trained to perpetuate westernised rule of law orthodoxy even though this so-called 'formal' justice system based on English and Roman-Dutch common law is unfamiliar, unhelpful and undesirable to many justice seekers. Westernised rule of law orthodoxy is often inaccessible to many South Africans due to geographical distance, language barriers and socio-cultural and spiritual ontologies, epistemologies and axiologies (Ruffin 2019; Martins 2016; Davids, et al. 2016). African indigenous justice systems (AIJS/ IJS) are part and parcel of a wider array of African indigenous knowledge systems (AIKS/ IKS). AIKS are herein defined as shared 'long-standing traditions and practices of cultural specific local African communities' (Kaya 2013: 136). These include valueladen belief systems and language conventions subject to intergenerational and experiential oral transfer. This paper highlights AIJS such as community-based justice systems (CBJS) and customary justice systems in South Africa. The CBJS example is the community advice office model. In other words, these justice systems are not operated by government but by independent community leaders. The focus is upon how such AIJS can be used as a tool for decolonising and indigenising legal education (LE). This tool can begin to undo cognitive damage wreaked upon students by law school curriculum that is currently epistemologically limited. The aim is to advance epistemic freedom of curriculum design and implementation beyond disciplinary borders. NdlovuGatsheni (2018: 17) opines that epistemic freedom speaks to cognitive justice and is contemporarily on the rise as a result of:

The definitive entry of descendants of the enslaved, displaced, colonised and racialized peoples into the existing academies across the world; proclaiming loudly that they are human beings, their lives matter, and that they were born into valid and legitimate knowledge systems Ndlovu-Gatsheni (2018: 17).

Ancient African polities functioned through similar constitutional principles underpinned by consensus democracy. Intricate judicial systems integrated law, politics, morality, ethics and spirituality in socio-cultural context as a way of life (Williams 1974). Today, in the absence or marginalisation of AIJS, westernised legal discourse remains hegemonic in LE. The Constitution of the 
Republic of South Africa (RSA 1996) is designed to redress the injustices of the country's colonial and apartheid past. Customary law is not only constitutionally permissible but also on an equal footing with English and Roman Dutch common law. Yet customary law and Europeanised law are epistemologically distinct. Law schools are the only provider of lawyers in the country but they do not fully integrate contextual and epistemologically sound customary justice systems into LE. This makes such law schools complicit, if not explicit in perpetuating structural inequality and privilege in society, thereby contravening the Constitution. Hence, a cultural interface of indigenisation and westernisation that deliberates critical standpoints in the context of LE is required. Questions often arise as to who should decolonise and indigenise LE, why and how should this be done? This paper helps answer these questions.

To some scholars, the legal profession has a colonising effect on LE (MacDonald \& McMorrow 2014). Hence, some studies reflect that nonindigenous law academics are unprepared or unwilling to indigenise LE or both, and that decolonisation of curriculum must be left to indigenous academics (McLaughlin \& Whatman 2008). Mere tinkering with curriculum, hiring Black law academics and inviting traditional authorities as guest speakers are insufficient for indigenising LE (Chartrand 2015). In contrast, and as I argue, a radical shift to African onto-epistemologies is critical to decolonising/indigenising LE and assessment practice. This is because settler colonialism is a structure and not an event (Wolfe 1999). The legal profession can be seen as an instrument of coloniality, which sustains after-effects of colonialism (Grosfoguel 2013). To Modiri (2018: 13, 17) even the South African Constitution 'represents a continuation and reproduction of the constituent elements of colonial conquest' given the 'tendency of constitutional scholarship to emphasise notions of rights, political equality, procedural democracy and good governance while bypassing larger questions of land, political economy, culture, identity and sovereignty tied to settlercolonial histories'. In considering the significance of land as a source of capital to colonisers, Tuck and Yang (2012: 5) contend that 'the disruption of Indigenous relationships to land represents a profound epistemic, ontological, cosmological violence. This violence is not temporally contained in the arrival of the settler but is reasserted each day of occupation'. This now autonomously functioning structuralism imposed by colonial settlers is deeply entrenched and ongoing. Such embedded structuralism pertains not just to land but also to other 
Indigenous relationships, such as ways of accessing justice. The IOTL and its AIJS were subjugated to centuries of colonialism and apartheid that, inter alia, stripped it of its original systems of checks and balances as well as gender equity. Ndulo (2011: 97) complains that this led to the 'bastardisation' of AIJS. This was never retracted. Hence, when colonial settlers used and when currentday academicians and scholars (irrespective of race) continue to use a westernised lens to observe and interpret AIJS, their understanding is likely distorted. African and westernised epistemologies of justice - including underlying values - differ (Ndima 2003). A cultural interface of justice systems could allow critical standpoints for deliberation. The deliberation is about equitable approaches that position critical standpoints at a cultural interface of different ways of knowing. This could facilitate epistemic freedom, LE transformation and broaden citizens' access to justice.

In South Africa, the Bill of Rights (RSA 1996) protects equality under the law (Section 9); human dignity (Section 10) and cultural, religious and linguistic freedom (Sections 30,31). The institution of traditional leadership (IOTL) along with domestic and international customary law are recognised in the Constitution (Sections 211, 212, 232). Customary law is given equal footing with English or Roman Dutch common law so long as each comports with the Constitution (Section 39). A majority of South Africans rely upon AIJS (Himonga \& Diallo 2017). Yet privileging rule of law orthodoxy over AIJS in LE blocks access to justice for the citizenry. This wreaks epistemic, ontological and cosmological violence on wider society generally and on law students particularly. Therefore, I further argue that failure to Africanise LE amounts to epistemicide, which violates the Constitution. African indigenous justice systems should be studied, interpreted and applied on their own merit and through African ways of knowing (AWOK). As subsequently discussed, AWOK advance non-dualism and community collective consciousness amongst other aspects. This paper provides guidance for lawyers, judges and the legal fraternity as a whole. For law academics and students, the paper suggests transdisciplinary-oriented yet legal profession-specific pedagogy that embraces complex legal problem-solving activities on an emancipatory trajectory. This is inclusive of socio-legal research through indigenous methodologies (Chilisa 2012), which can in turn inform LE curriculum development beyond borders.

This article is organised as follows. Firstly, this introduction is followed by research methods. Then, the results and discussion section is divided into 
three subparts. Epistemic freedom as an unfolding imperative for indigenising LE is discussed. Next, selected aspects of South African legal pluralism are presented as a tool for indigenising or Africanising legal education. The article then goes on to answer the query of who should Africanise LE, why and how? Finally, the article provides conclusions and recommendations.

\section{Methods}

This conceptual study is based on discourse analysis and interpretivism. Discourse analysis is a useful tool for the critical study of power and inequality as a social problem (Van Dijk 1997: 32). Here, the problem revolves around the hegemony of the westernised legal system and profession that tend to colonise law schools. This is a social problem in a legal pluralist country like South African where millions of citizens select non-state justice systems to administer disputes. Yet these justice systems are not taught in epistemological and socio-cultural context during LE. This perpetuates the structure of settler colonialism and inequality of African indigenous legal traditions. Interpretivism deals with concepts 'of everyday talk, lives, and written or depicted record of situational actors and/or embedded within a literature, as a historicised backdrop for scholarly thinking' (Yanow \& Schwartz-Shea 2010: xix). Towards that end, AIKS, legal pluralism and decolonisation of LE were key words used to obtain secondary sources. Literature was accessed through electronic search engines based on law and humanities through African Journal Archives, Digital Access to Scholarship at Harvard, EBSCOhost, Google Scholar, Hein-online, Ingenta Connect, JSTOR, Lexis/Nexis, and Sabinet. Hence, this study used the interpretive method and discourse analysis to examine how legal pluralism could be used to decolonise LE. In line with indigenous methodologies, the interpretation was done in a subjective but scientific manner (Zhang \& Wildemuth 2009) and in light of experientialism, including the author's more than three decades as a lawyer and AIKS practitioner and more than a decade as an academic. The results and discussion follow.

\section{Results and Discussion}

\section{Epistemologies as Unfolding Imperatives}

A law degree is a gateway to the legal profession. The legal profession is held in high esteem in most countries throughout the world. LE is not developed in 
isolation. Rather, law schools must be accountable to an array of professional bodies and oversight organisations that determine and hold the 'keys' for admission to the legal profession. LE must prepare students for national board examinations that may, in part be specific to subnational contexts such as provinces and states. This education is largely built on westernised rule of law orthodoxy. Rule of law orthodoxy is perpetuated by law schools and law professors, and executed by lawyers, judges and other actors in the dominant legal system. However, in global North and global South countries alike, the dominant or so-called 'formal' justice system is not the sole justice system by which individuals and organisations handle their legal affairs. In countries such as Australia, Canada, Iraq, New Zealand and the United States, people still abide by long-standing IJS that are socio-culturally informed and take into account ways of knowing that predate rule of law orthodoxy (Borrows 2016; Chartrand 2015; Hamoudi 2014). Ancient justice systems existed in global South countries long before the onset of colonisation, chattel slavery, imperialism, apartheid and other such impositions (Asante 1965).

In higher education (HE) generally, there has been a call for decolonisation of curriculum (Maldonado-Torres 2011; Ndlovu-Gatsheni 2018). Legal education, not unlike other HE curricula is based on tenets of westernised ontologies, epistemologies, axiologies and cosmologies. Westernised and African worldviews differ (Teffo 2011). This is why critical standpoints should be positioned at a cultural interface of deliberation to advance curriculum transformation. The reader is cautioned not to essentialise, valorise or demonise any worldview. Rather, the purpose is to grasp an understanding of different worldviews as a bridge to inclusivity and social cohesion. From a westernised perspective, ontology, epistemology, axiology and cosmology are perceived as distinctive relatively standard concepts that play different roles in compartmental ways - just as disciplines are separated in the academy (Nabudere 2011). Nabudere explains that:

Plato ... created a hierarchisation and distinction between ideas or forms and things, and between the inside and outside of things - and hence virtue and knowledge. From now on in the Greek understanding, the thing and its form (the idea) were no longer organically linked. This was a characteristic of the European mythoform, in which things were viewed dualistically as opposites .... A duality between the inside and outside was created, and this is how dualism entered the whole 
structure of European thought through the Christian religion (as per St. Augustine) as well as the academic disciplines in the form of dialects (Nabudere 2011: 27) (e.i.o.).

In contrast, African worldviews conceive these concepts as a dynamic oneness that signals a transdisciplinary approach (Nabudere 2011; Ruffin, Teffo \& Kaya 2016). Therefore, AWOK, as used herein, includes African ontologies, epistemologies, axiologies and cosmologies. McDougal (2014: 236) contends that AWOK entail the character of realism, definition of truths and interrogation of the relationship between 'the knower, knowing and the known'. This includes what can be known, what is considered knowledge and how such knowledge can be applied. AWOK encompasses humanistic and societal factors (Wa Thiong'o 2009) as well as the socio-cultural environment (Mungwini 2013: 87). AWOK unites theories and the knower's character (Teffo, 2011: 24); and advances non-dualism and community collective consciousness (Masolo 2012: 25). AWOK should be used to study AIKS which are 'long-standing traditions and practices of cultural specific local African communities' including 'skills, innovations, wisdom, teachings, experiences, beliefs, language and insights' generated by and beneficial to these communities for their sustainable livelihoods (Kaya 2013: 136; Dei 2012). AWOK are further distinguishable to Western epistemologies in law and values as subsequently explored (Cobbah 1987: 330). These points suggest that AIKS should be rigorously studied and taught on their own merit and not simplistically as dichotomous to westernised ways of knowing and being. Failure to study AIKS on their own merit amounts to committing epistemicide, which is oppressing varied worldviews (Sandoval, Lagunas, Montelongo \& Díaz (2016: 19) and upholding cognitive imperialism (Battiste 2017). This the South African Constitution forbids.

Scholars, researchers and professors, including anthropologists, archaeologists, and sociologists as well as jurists, missionaries and other actors in the European-driven imperialist project postulated their theories and beliefs about what they perceived to be AIK and AIKS. These theories and beliefs are now embedded, for example, in westernised education systems across disciplines and countries - based on colonial settler observation and westernised ways of knowing. The IOTL and its AIJS were stripped of their original mechanisms of checks and balances as well as gender equity, at the behest of and domination and control of colonial settlers (Ruffin 2018). This 
was never retracted. Therefore, the IOTL and its AIJS should likewise be critically interrogated to advance them as systems of epistemic freedom (Ndlovu-Gatsheni 2018). The so-called 'official' customary law was imposed and is distinguishable from living African law (Ndima 2003; Himonga \& Diallo 2017). Ndima (2003) explains:

"Official" African law represents a distorted system devoid of social context in that it was pruned of its essence in an official bid to rid it of those aspects of indigenous tradition that were viewed as repugnant to Christian and Western values (Ndima 2003: 344).

The 'official' codified African or customary law was not indigenously constructed, but drawn by colonial and apartheid architects. Examples are the Black Administration Act 38 of 1927 and a series of other codes along with construction and treatment of case precedents to serve the interests of colonial settlers. Even until today some aspects of that Black Administration Act regulate certain aspects of customary courts. Himonga \& Diallo (2017: 5-6) term these examples 'old order' customary law with the 'new order' being post-1994 legislation 'aimed at transforming indigenous institutions within African constitutional frameworks' such as customary marriage and customary law of succession reforms. Unlike 'official' customary law, living African law is indigenously driven, dynamic and reflective of African values and traditions with its socio-cultural context intact. The epistemological challenge comes when 'official' customary law and/or living African law cases come before rule of law orthodoxy jurists who may or may not interpret these cases with due regard to socio-cultural and socio-legal contexts pursuant to AWOK (as shown in section 3.2). This is one of the reasons for advantaging legal pluralism to Africanise LE. Law students become lawyers and jurists who should be wellversed in AWOK to meet constitutional mandates of ensuring human dignity, equality before the law and so on. Globally, indigenous knowledge and IKS are still seldom approached, studied, contemplated or written about using indigenous ways of knowing. Rather, not unlike the IOTL and its AIJS, educational, health and other systems were altered and disjointed from AWOK (Williams 1974). Therefore, these systems too must be epistemologically liberated in a way that incorporates AWOK into the contemporary era, alongside other knowledge systems in the interests of complementarity.

In this article, decolonisation, indigenisation and Africanisation are 
distinguishable yet interactive. Bolivia's example of rejecting neoliberal educational reforms postured by the World Bank and International Monetary Fund but devoid of input from teachers and civil society provides a useful example (Lopes, Cardozo \& Strauss 2012). Bolivia used an endogenouslydriven amalgamation of inter-culturalism, intra-culturalism, pluri-lingualism and communitarian approaches to indigenise curriculum that sustain reflection and growth of one's identity in relation to others throughout the educational experience and toward pluri-national citizenship (Lopes, Cardozo \& Strauss 2012). In other words, the 'intra-culturalism' required introspection of students without diminishing their own ancestral-inspired ways of knowing while contributing to and growing from other bodies of knowledge. Hence, decolonisation meant rejection of neoliberal approaches to educational reform and indigenisation became growth and development of one's ways of knowing, including use of indigenous languages, in relation to others. This shows interactivity between decolonisation and indigenisation. This demonstrates how to undo cognitive damage done to students by global North-centric curriculum design and implementation.

The 'intra-culturalism' component is particularly insightful for this discussion on indigenising LE. It is not inconceivable that black African students whose ancestors are indigenous to the continent - such as Zulu and Xhosa people - could be embarrassed by AWOK that, for example, include slaughtering of animals to appease ancestors in resolution of legal disputes. It is not unrealistic to even presume that a westernised LE could be seen as a way to improved economic and professional status; that AWOK are backwards and unworthy; that AWOK should be abandoned in favour of westernised religion, practices and belief systems built on individual-based human rights as well as animal rights. The 'intra-culturalism' component applied in Bolivia would require such law students to, for instance, introspectively reflect on the role of ancestors in their culture. Since AIJS demonstrate reconfiguration of systems advanced by colonisation and apartheid, such law students may perceive traditional leaders as individualistic and inhumane and AIJS unfit for handling legal disputes. Tribunal members may appear more concerned with personal gain than community sustainability, growth and development. In other words, black African law students may be unaware of or even devalue their own historical socio-cultural values that existed in pre-colonial Africa. The same is true for African indigenous law academics. This situation complicates indigenisation and Africanisation of LE but need not hinder it with the 'intra- 
culturalism' component in place. The 'intra-culturalism' component could begin to unravel the African origin of constitutional principles and consensus democracy (Williams 1974) or the link between the Egyptian Mysteries System and Hugo Grotius' development of International Law (Ruffin 2009). This could in turn help decolonise and Africanise LE.

Returning to the interaction between decolonisation, indigenisation and Africanisation, decolonisation is concerned with dismantling the hegemony of westernisation. To speak only of decolonisation is to continue a reactive focus on colonisation. Indigenisation denotes a global linkage to indigenous peoples and cultures all over the world (Gilbert 2017). Africanisation is a process of honouring, remembering, building, fortifying and continuing to discover AWOK. Neither indigenisation nor Africanisation, for the purposes of this discussion involve elimination of westernised epistemologies. Rather, a proactive approach through indigenisation and Africanisation of LE may open avenues for AIJS to contribute to the global pool of jurisprudence alongside other bodies of legal knowledge. Such avenues are closed by current LE which is steeped in legal positivism and designed to inculcate law students with a centralised legal mind (Hamoudi 2014). This is next discussed.

\section{Selected Aspects of South African Legal Pluralism}

Legal pluralism is subject to a number of meanings and what constitutes law is controversial. Legal pluralism is often constructed as social fact legal pluralism or normative pluralism (Merry 1988; Tamanaha 2008; Twining 2010). This is seemingly done to acknowledge existence of non-state justice forums, but to avoid characterising these systems as legal. Roberts (1998) advocates against legal pluralism. Twining (2010: 48-49) bases his social fact view of legal pluralism on legal positivism and includes 'coexistence of two or more autonomous or semi-autonomous legal orders in the same time-space context'. Pimental (2011) contends that, in post-colonial Africa, there are at least three conceptual approaches to legal pluralism: namely the colonial, superior state and equal dignity approaches. The first means the restructuring of the customary justice system to meet the needs of colonisers. The second denotes constitutional acknowledgement of customary law but rule of law orthodoxy reigns supreme. The third indicates distinct systems whereby AIJS include socio-cultural contexts in administering justice. While aspects of the 
colonial approach arguably remain in South Africa, the superior state approach is prevalent. However, if LE was adequately Africanised, treatment of the customary justice system could encompass an equal dignity approach consistent with the South African Constitution. This would mitigate legal centralism.

Legal centralism ensures 'that only law made by the state or specifically allocated to others by the state' is conclusive (Hamoudi 2014: 145). Twining (2010) acknowledges that state-centrism and legal centrism are recent, existing largely in the global North for less than 200 years. Longstanding non-state legal systems across the global South and North, even if destructed or tainted during colonisation, continue to function (Williams \& Klusener 2013; Skelton 2011). When legal scholars are at a loss to perceive non-state legal systems as such, but can only envisage rule of law orthodoxy as law, there is another level of colonisation - intellectual colonisation. Hamoudi (2014: 136) highlights 'the need to decolonise the legal mind away from legal centralism and reacculturate the rule of law community to the realities of legal pluralism'.

Decolonisation of the centralist legal mind can begin to occur with an awareness of AWOK and epistemological distinctions that underlie diverse justice systems. South African legal systems are found at least in the IOTL, the Islamic Shari'a, community-based legal advice offices, and westernised rule of law orthodoxy. Millions of South Africans exercise forum shopping when faced with legal matters and some choose non-state justice systems. Simultaneously, LE provides little or no exposure to such non-state justice systems. Table 1 depicts two non-state justice systems and the westernised state justice system. The characteristics underlying the systems help reveal underlying epistemologies.

Informal CBJS exist throughout the world (Maru \& Gauri 2018; Wojkowska 2006). In South Africa, community-based paralegals (CBPs) operate in various forms, including those in community advice offices (CAOs). CBPs are trained in public LE and administration, live in the communities where CAOs are located, speak the local language and practice local cultures (Martins 2016; Ruffin \& Martins 2016; Dugard \& Drage 2013). Similarly, amakosi (traditional leaders), izinduna (headmen/women) and community elders are closely linked to local communities, language and culture. In contrast, proponents of rule of law orthodoxy, such as lawyers and judges are generally not as culturally and geographically linked to the populace served as compared to non-state justice system implementers. Thus, Table 1 suggests 
that, as to the leadership characteristics of the three justice systems, the interactive relationship between 'the knower, knowing and the known' (McDougal 2013: 236) is more closely aligned with non-state justice systems and communities served than with judges, lawyers and litigants served by the latter.

Table 1. Selected distinctions in parallel justice systems

\begin{tabular}{|l|l|l|l|}
\hline Characteristics & \multicolumn{3}{|c|}{ Justice Systems } \\
\cline { 2 - 4 } & $\begin{array}{l}\text { Community- } \\
\text { based justice } \\
\text { system }\end{array}$ & $\begin{array}{l}\text { Customary justice } \\
\text { system }\end{array}$ & $\begin{array}{l}\text { Nation-state justice } \\
\text { system }\end{array}$ \\
\hline Leadership & $\begin{array}{l}\text { Mediation by } \\
\text { paralegals }\end{array}$ & $\begin{array}{l}\text { Traditional court, } \\
\text { amakosi, iziduna, } \\
\text { community elders }\end{array}$ & $\begin{array}{l}\text { Legislators, judges, } \\
\text { lawyers }\end{array}$ \\
\hline Methods & $\begin{array}{l}\text { Case-by-case } \\
\text { decisions, } \\
\text { socio-cultural } \\
\text { context }\end{array}$ & $\begin{array}{l}\text { Case-by-case } \\
\text { decisions, socio- } \\
\text { cultural context }\end{array}$ & $\begin{array}{l}\text { Statutes and case } \\
\text { precedents }\end{array}$ \\
\hline $\begin{array}{l}\text { Socio-cultural } \\
\text { context }\end{array}$ & $\begin{array}{l}\text { Ancestral } \\
\text { relevance in } \\
\text { decision- } \\
\text { making }\end{array}$ & $\begin{array}{l}\text { Ancestral relevance } \\
\text { in decision-making }\end{array}$ & $\begin{array}{l}\text { Devoid of socio- } \\
\text { cultural/spiritual } \\
\text { context }\end{array}$ \\
\hline $\begin{array}{l}\text { Decision- } \\
\text { making }\end{array}$ & $\begin{array}{l}\text { Parties to } \\
\text { dispute make } \\
\text { ultimate } \\
\text { decisions }\end{array}$ & $\begin{array}{l}\text { Public participation } \\
\text { in proceedings with } \\
\text { consensus decision- } \\
\text { making by } \\
\text { Traditional Court }\end{array}$ & $\begin{array}{l}\text { Non-participation of } \\
\text { litigants in ultimate } \\
\text { decision, judge as }\end{array}$ \\
\hline $\begin{array}{l}\text { Individual or } \\
\text { collective } \\
\text { context }\end{array}$ & $\begin{array}{l}\text { Families may } \\
\text { be involved in } \\
\text { decision- } \\
\text { making }\end{array}$ & $\begin{array}{l}\text { Community } \\
\text { considerations } \\
\text { matter }\end{array}$ & $\begin{array}{l}\text { Individual rights- } \\
\text { based claims of } \\
\text { litigants }\end{array}$ \\
\hline Remedies & $\begin{array}{l}\text { Remedies } \\
\text { agreed upon by } \\
\text { disputants }\end{array}$ & $\begin{array}{l}\text { Fines or penalties } \\
\text { paid to the wronged } \\
\text { party }\end{array}$ & $\begin{array}{l}\text { Prescribed fines or } \\
\text { penalties paid to the } \\
\text { state }\end{array}$ \\
\hline
\end{tabular}




\begin{tabular}{|l|l|l|l|}
\hline Outcomes/aims & $\begin{array}{l}\text { Forward } \\
\text { thinking } \\
\text { sustainable } \\
\text { solutions }\end{array}$ & $\begin{array}{l}\text { May include animal } \\
\text { sacrifice for } \\
\text { resolution }\end{array}$ & $\begin{array}{l}\text { Decision appealable } \\
\text { or terminal }\end{array}$ \\
\hline
\end{tabular}

Sources: Martins (2016); Williams and Klusener (2013); Ntlama and Ndima (2009).

The two non-state justice systems are connected to AWOK whilst rule of law orthodoxy is bound to westernised neoliberal discourse (Ruffin \& Martins 2016; Krever 2011). Rule of law orthodoxy is governed by the concept of adversarial judicial proceedings and an impartial judiciary, whereas CBPs serve as neutral mediators and AIJS strive for consensus-building, guided by a presiding officer. Hence, the non-state justice systems are more concerned with restorative justice as opposed to winners and losers in the state justice system (Ruffin 2019). Nevertheless, for decades, rule of law orthodoxy conventions have been increasingly expanding into various forms of alternative dispute resolution (ADR) mechanisms (Edwards 1986; Hensler 2003; MenkelMeadow, Porter-Love, Kupfer-Schneider \& Moffitt 2018). A Canadian study on cost implications of ADR found that, inter alia, it takes twice as long and costs twice as much to resolve disputes through litigation instead of ADR. Whilst lawyers surveyed preferred ADR, litigation remains widely used (Paetsch, Bertrand \& Boyd 2018). In that respect, it seems that westernised epistemologies of justice tend to prevail. Unlike rule of law orthodoxy, the socio-cultural context applies in both non-state justice systems and AIJS are somewhat historically informed. However, as scholars point out, official customary law is distinguishable from unofficial living African law. Living African law was deconstructed and reconstructed, with the help of amakosi, to meet the needs of colonial settlers and the apartheid regime; thereby ensuring that, where underlying epistemologies and values differed, the westernised version would prevail over Indigenous law (Ndima 2003; Skelton 2011). On the one hand, rule of law orthodoxy metes out justice through application of statutes and case precedents in a compartmentalised way. On the other hand, these two non-state justice systems deliver services through fluid case-by-case decisions that are embedded in the socio-cultural context of communities: through AWOK (Mungwini 2013). This comparative analysis highlights a range of critical standpoints for deliberation at a cultural 
interface of justice systems, justice providers and justice seekers.

Cobbah (1987) indicates that whilst the rule of law is projected as value-free and objective, African epistemologies of justice are embedded with values, culture and custom. A value-based distinction between the two nonstate systems shown in Table 1, juxtaposed against the nation-state justice system, is that the former systems are more concerned with communal duties to avoid collective shame. Decision-making in CAOs operated by CBPs revolve around disputants determining the outcome and may include families in decision-making to build sustainable futuristic solutions to which parties and their families independently commit (Martins 2016; Dugard \& Drage 2013). Customary courts include not only community elders on the tribunal but also public participation from onlookers and disallowance of legal representation of parties in favour of consensus-building (Ntlama \& Ndima 2009). Studies show that CAOs and the customary justice system regularly interact with each other through case referrals and dispositions (Martins 2016, Drake \& Drage 2013). These two systems suggest incorporation of humanistic and sociocultural factors in dispute resolution (Ruffin \& Martins 2016), unity of jurisprudence and character (Teffo 2011), and advancement of holism and community collective consciousness (Masolo 2012). All of these are typical characteristics of AWOK. In contradistinction, rule of law orthodoxy is based on individual-rights claims where parties' individual interests are advocated by argumentatively persuasive lawyers and ultimately determined by a judge. Nevertheless, there is a weight of literature that contends that customary courts are self-serving, and traditional leadership corrupt and discriminatory toward women. This article does not engage this debate. The point is that official customary law should be decolonised and indigenised with living African law. As subsequently discussed, this could be done in part through law school assessment practice to prepare future lawyers and jurists.

Spirituality is a basic tenet of AWOK. Generally, AIJS such as the two discussed here consider the role of spiritual/supernatural forces in procedure, outcome and restoration objectives (Cobbah 1987). As to remedies and outcomes, customary courts seek to restore wholeness by the perpetrator paying fines to an aggrieved party or offering animal sacrifice to appease ancestors. Ancestors are participants in restoring holism and healing human-made psycho-social wounds. In rule of law orthodoxy, statutory fines are paid to the state. Although damages may be paid to the winning party in, for example, personal injury or contract cases, there is no spiritual healing component. 
These are the types of epistemological distinctions that should be taught and researched in LE. Decisions in customary courts may be appealed to the state courts and state court decisions are appealable up the hierarchy of that court system.

However, appeal of AIJS cases to the state court evidences consequences of epistemological distinctions. South African courts have either emphasised the need to develop Indigenous law in line with the Bill of Rights or refrained from doing so. See, for example, Bhe v Magistrate, Khayelitsha (Commission for Gender Equality as Amicus Curiae), Shibi v Sithole, and the South African Human Rights Commission v President of the Republic of South Africa (2005); Mabena v Letsoalo (1998); Nkabinde v Road Accident Fund (2001); Ramoitheki v Liberty Group Ltd t/a Liberty Corporate Benefits (2006). At times, even when the court applies Indigenous (or customary) law, it insufficiently interrogates cases to allow Indigenous law to develop. The court has been known to retreat to legal centralism and positivism and apply Europeanised common law to Indigenous law cases; such as the above mentioned Bhe case (Ndima 2003; Himonga \& Diallo 2017). Similarly, as Ntlama (2009) contends, the court failed to consider past practices of 'official' Indigenous law or further back into living African law when deciding the customary law of a succession case, Shilubana v. Nwamitwa (2009). In that case, 'the essence of the customary law rule of succession to chieftancy was completely undermined by the lack of a proper understanding of the rationale and authority of customary law and the manner in which it operates' (Ntlama 2009: 354). The court is inconsistent in showing an awareness of the role of ancestors in AWOK. For instance, the court declined to interpret indigenous spirituality and burial practices as part of 'family life' in Nkosi v Bührmann (2002). However, the spiritual practice of interment of deceased family members in close proximity to the family homestead was acknowledged by the court in Dlamini v Joosten (2005). This brings to bear one of two factors. Firstly, jurists and lawyers either lack knowledge about AWOK underlying Indigenous law from time immemorial and the IOTL as a whole - precolonialism, during or post-colonialism. Or, secondly, lawyers and jurists are unwilling to use Indigenous law to decolonise the rule of law orthodoxy system. Both scenarios perpetuate privileging westernised epistemologies over AWOK. This also deprives Europeanised common law from growing through the use of Indigenous law.

Sections 39 and 173 of the South African Constitution vest courts with 
the power to develop Indigenous law and common law. Section 211 provides in pertinent part that the court 'must' apply Indigenous law when applicable. Yet, externally imposed Europeanised common law by colonial settlers seems to take precedence over Indigenous law, even though there are constitutional obligations and case precedents obliging courts to allow Indigenous law to develop on its own merit within the Bill of Rights. Section 235 substantiates the 'right of self-determination of any community sharing a common cultural and language heritage'. How common is Europeanised common law to millions of South Africans who rely upon customary justice systems that are more consistent with their values and culture? To allow Europeanised common law to speak for Indigenous law sustains coloniality. It is analogous to Madlingozi's (2010) point that exogenously driven well-meaning transitional justice experts speak about or on behalf of victims in reckless disregard of underpinning worldviews of victims' stories. Indigenous law should not be treated as dependent on or a victim of English common law. In effect, the court's unawareness or obliteration of the socio-cultural context of Indigenous law raises grave concerns. These could begin to be addressed by Africanising LE. Highlighting epistemological distinctions underlying plural legal systems could be both a tool for decolonising and Africanising LE and a source of continuing professional development for lawyers, judges and law societies. This requires studying Indigenous legal traditions and CBJS on their own merit (Chartrand 2015). The cultural interface of emerging critical standpoints within different justice systems can help facilitate the process. The question is often raised as to who should decolonise/indigenise LE, why and how? This is next discussed below.

\section{Who Should Africanise Legal Education, Why and How?}

Thus far, it seems that decolonisation and Africanisation are required at various levels. These include the centralist legal mind, LE, legal profession, westernised justice system, IOTL and official customary law. The concern here is with the centralist legal mind and LE. Borrows (2016: 795, 807) opines that 'teaching of Indigenous peoples' law should be done in culturally appropriate ways that open rather than confine fields of inquiry within Indigenous law and practice' and highlights the 'requirement of working with communities.... and of paying Indigenous legal practitioners at appropriate law school scales'. A group of professors at the Canadian Faculty of Law at the University of Ottawa, 
with expertise in Indigenous law, set an intermediate goal of including an Indigenous law stream in its LE. They did so without sacrificing unique epistemologies inherent in Indigenous legal traditions such as Algonquin, Haudenasoanee and Innu. They established a long-term goal of offering common law, civil law and Indigenous law of various traditions (Chartrand 2015). The Law and Justice Faculty at the Australian University of Queensland implemented an Embedding Indigenous Perspectives project, which was hindered by non-Indigenous academics being unable to move beyond whiteness and privilege (McLaughlin \& Whatman 2008:144). That study therefore found that Indigenous educators must 'champion the struggle against colonial forms of domination within academic institutions' and with their supporters, 'decolonise constructed knowledge of the 'other'. Intellectual colonialism should not be an excuse for non-participation in decolonisation and indigenisation of curriculum. Rather, this effort should be epistemologically-driven, not race-based. AWOK can be learnt by non-Indigenous people just as most people in the world have learnt westernised ways of knowing. In both the Canadian and Australian efforts, inclusion of Indigenous peoples in curriculum development was recognised.

According to Chartrand (2015: 9), 'law is much richer and deeper than Western legal thought'. To plan and deliver an emancipatory LE, decolonising and indigenising/Africanising LE and assessment practice should be a collective endeavour. This would include onto-epistemologically equipped academics (even descendants of colonial settlers who remain privileged by colonial and apartheid legacies), traditional leaders, AIKS practitioners, living African law knowledge-holders, and AIKS researchers skilled in socio-legal studies and indigenous methodologies. This epistemologically based activity brings to the fore 'cultural interface' and 'critical standpoints' of this array of actors (Nakata 2007; Carey \& Prince 2015). Hence, irrespective of national origin or whether of indigenous or settler colonial realities, an interactive cultural interface of knowledge holders is required whereby one moves beyond binaries and does not seek to replace or valorise one's culture or knowledge system over another. Instead, the need exists to honour critical standpoints undergirded by various epistemologies, interrogate knowledge systems and work together so that all knowledge systems contribute to the global pool of knowledge. As uncomfortable as this may be to some law academics, it is necessary to decolonise/indigenise/Africanise LE, particularly in a legal pluralist society like South Africa. 
Legal education should be indigenised/Africanised for a number of reasons. Firstly, a recognition and acceptance that colonisation, apartheid, imperialism and neoliberalism have managed to obscure and denigrate legitimate AIJS is necessary to move forward. Secondly, a self-motivated interest in upscaling jurisprudence to meet justice delivery requirements in a contemporary knowledge economy is a driving force. Thirdly, the United Nations Declaration of Rights of Indigenous Peoples entitles justice seekers to access Indigenous legal institutions (UN DRIP 2007). Fourthly, the South African Constitution and Bill of Rights protect customary law underpinned by the desire for democratic governance and legal empowerment of all is another reason. Simultaneously, there is a growing body of work that contests South African constitutionalism (e.g. Modiri 2018). Such deliberate critique advances Africanisation of LE. Finally, expanded legal careers for lawyers could be achieved. Synergies emerge from sharing different legal philosophies and epistemologies across cultures and legal traditions. Failure to do so ignores ideals of education, lessens competencies of legal professionals (Chartrand 2015); and derogates from the Constitution. Decolonisation of the legal academy offers opportunities for consensual relationship-building (Barrows 2016). Tinkering with curriculum and hiring indigenous/black academics is insufficient. Decolonisation of the centralist legal mind requires willpower and applies to anyone who experiences westernised LE. Nation-state centrism and legal centrism/positivism are endemic to the compartmentalised tendency of westernised ways of knowing. Yet, the majority of the world's population are of non-westernised origin. Such hegemony disempowers citizens seeking legal traditions that recognise socio-cultural and socio-spiritual elements of life force.

In South Africa, Modiri (2016) and Himonga and Diallo (2017) provide insight into decolonising/Africanising LE as shown in the first two columns of Table 2 . The third column depicts contributions from this article.

\section{Table 2 Strategies for Decolonisation/ Indigenisation/ Africanisation of LE}

\begin{tabular}{|l|l|l|}
\hline Modiri (2016) UP & \multicolumn{1}{|c|}{$\begin{array}{c}\text { Himonga \& Diallo } \\
\text { (2017) UCT }\end{array}$} & Ruffin (2019) UKZN \\
\hline $\begin{array}{l}\text { Critically engaged } \\
\text { pedagogical } \\
\text { approaches }\end{array}$ & $\begin{array}{l}\text { Teach living African } \\
\text { law }\end{array}$ & $\begin{array}{l}\text { Advantage legal pluralism } \\
\text { through student-driven } \\
\text { research }\end{array}$ \\
\hline
\end{tabular}




\begin{tabular}{|l|l|l|}
\hline $\begin{array}{l}\text { Multiple } \\
\text { intellectual } \\
\text { paradigms and } \\
\text { epistemologies }\end{array}$ & $\begin{array}{l}\text { Paradigm shift from } \\
\text { legal positivism/ } \\
\text { centralism to legal } \\
\text { pluralism }\end{array}$ & $\begin{array}{l}\text { Apply onto-epistemologies } \\
\text { to assessment practice and } \\
\text { Nakata's (2007) 'cultural } \\
\text { interface and critical } \\
\text { standpoints' }\end{array}$ \\
\hline $\begin{array}{l}\text { Interrogate and } \\
\text { address socio- } \\
\text { political context }\end{array}$ & $\begin{array}{l}\text { Interdisciplinary } \\
\text { research }\end{array}$ & Transdisciplinary research \\
\hline
\end{tabular}

As Table 2 reveals, different scholars in three universities across as many provinces have similar ideas. This article further interjects steps for stakeholder engagement for cross-border curriculum development and emancipatory assessment practice. The 'cultural interface' and 'critical standpoints' calls together previously mentioned actors to help facilitate the Africanisation of LE project (Nakata 2007; Carey \& Prince 2015). Cultural and critical interchange and exchange across disciplines and between the university and society are paramount. All views are valued and consensus-building encouraged. This would help decolonise the centralist legal mind and enable recognition that the univocal (Modiri 2016) and monism (Himonga \& Diallo 2017) tendencies of the discipline of law are ripe for dissolution. Consistent with AWOK, this collaborative endeavour could also include relevant provincial offices of Cooperative Governance and Traditional Affairs (COGTA), which would attract the House of Traditional Leaders. The Department of Science and Innovation and the DST-NRF Centre in Indigenous Knowledge Systems could likewise be involved as they are nationally committed to protection, coproduction and application of AIKS pursuant to the South African Indigenous Knowledge Policy (RSA 2004) and the Indigenous Knowledge Act 6 of 2019 (RSA 2019). Actors in this proposed working group for Africanisation of LE would set agendas and execute shared tasks. This collaboration would require more time than financial resources.

Finally, turning to assessment practice, Africanising LE can include complex legal problem-solving assessment activities on an emancipatory trajectory. Emancipatory education entails multi-inter-transdisciplinary and pluri-paradigmatic approaches to co-produce knowledge. Examining critical standpoints at the cultural interface juncture is useful. An example is ethnographic approaches to law (Darian-Smith 2016). Rigorous student engagement revolves around interrogating real-life scenarios requiring 
transdisciplinary enquiry and varied innovative legal remedies. For example, socio-legal research problems investigated with indigenous methodologies move students beyond law in books to the dynamism of living African law. Actors involved in the LE Africanisation project are likewise rich sources of research. Research findings can offer fresh real-life perspectives on living African law and AWOK can then be funnelled into further curriculum development. Grounded research outcomes can help create professional development curriculum for lawyers, judges and law professors. Then knowledge of living African law is acquired and thereafter interpreted within its socio-cultural context during judicial review of AIJS cases. Similarly, research outcomes can enable law academics to equip themselves and law students with AWOK and legal pluralist versatility so as to undo cognitive damage. Such assessment practice could also begin to decolonise the IOTL and AIJS through action research so that Indigenous law can develop on its own merit yet consistent with the Bill of Rights. Moreover, this assessment practice can enable living African law to inform Europeanised common law. Collective duties inherent in AWOK could enhance legal dispositions as opposed to individualistic proclivities that spur winners and losers. This could likewise advance social cohesion in the country.

\section{Conclusions and Recommendations}

Legal pluralism is more than just a social fact in African countries. It is a sociocultural-legal reality for those who choose non-state justice systems to resolve disputes. This article highlighted onto-epistemological, axiological and cosmological distinctions underlying CBJS, the customary justice system and westernised justice systems. Several conclusions are drawn. Firstly, the hegemonic privileging of rule of law orthodoxy diminishes usefulness of AIJS, requiring a radical shift to African onto-epistemologies in LE and assessment practice. Secondly, legal pluralism, taught in relevant onto-epistemological contexts can be a tool for decolonising and Africanising LE. Thirdly, failure to epistemologically study and critically historicize and interrogate South African legal plurality perpetuates cognitive damage to professors and students alike whilst generating a justice deficit for South African citizens. Finally, indifference to Africanisation of LE flouts the Constitution.

It is recommended that: 
- Law professors of different ethnic backgrounds embark upon 'cultural interface' and 'critical standpoints' with each other and with AIKS legal practitioners (including the IOTL) and indigenous methodology researchers to design curriculum that fits the South African context, grounded in AWOK.

- Modules that incorporate Indigenous law or that are independently created must protect the socio-cultural and overarching spiritual context inherent in the dynamism and fluidity of living African law.

- Assessment practice should move beyond law and sociology of law in books to socio-legal research through indigenous methodologies, with research problems designed to interrogate living African law so that it develops on its own merit.

- Findings from socio-legal research and indigenous methodologies should be used to decolonise and indigenise LE.

- LE should aim to decolonise the centralist legal mind, the IOTL and eventually the legal profession through production of a new cadre of law school graduates who would in turn facilitate decoloniality of the legal profession and law schools.

- LE should set the tone for establishing portals of continuing professional development for lawyers, judges and lawmakers; underpinned by AWOK.

The liberation trajectory espoused is not for the faint at heart, but requires willpower to begin to introspectively unshackle one's own centralist legal mind.

\section{References}

Asante, S.K.B. 1965. Interests in Land in the Customary Law of Ghana: A New Appraisal. The Yale Law Journal 74,5: 848 - 885.

https://doi.org/10.2307/794709 
Battiste, M. 2017. Decolonizing Education: Nourishing the Learning Spirit. Vancouver: UBC Press.

Bhe v Magistrate, Khayelitsha (Commission for Gender Equality as Amicus Curiae), Shibi v Sithole, South African Human Rights Commission v President of the Republic of South Africa ([2005] 1 SA 580 (CC)).

Borrows, J. 2016. Heroes, Tricksters, Monsters, and Caretakers: Indigenous Law and Legal Education. McGill Law Journal/ Revue de droit de McGill 61,4: 795 - 846. https://doi.org/10.7202/1038489ar

Carey, M. \& M. Prince 2015. Designing an Australian Indigenous Studies Curriculum for the Twenty-first Century: Nakata's 'Cultural Interface', Standpoints and Working Beyond Binaries. Higher Education Research \& Development 34,2: 270 - 283.

https://doi.org/10.1080/07294360.2014.956691

Chartrand, L. 2015. Indigenizing the Legal Academy from a Decolonizing Perspective. Ottawa Faculty of Law Working Paper No. 2015-22. Available at:

https://papers.ssrn.com/sol3/papers.cfm?abstract id=2631163

(Accessed on 02 November 2017.)

Chilisa, B. 2012. Indigenous Research Methodologies. London: Sage Publishers.

Cobbah, J.A.M. 1987. African Values and the Human Rights Debate: An African Perspective. Human Rights Quarterly 9,3: 309 - 331.

https://doi.org/10.2307/761878

Darian-Smith, E. 2016. The Crisis in Legal Education: Embracing Ethnographic Approaches to Law. Transnational Legal Theory. Available at: $\underline{\text { http://dx.doi.org/10.1080/20414005.2016.1176790 }}$

(Accessed on 10 August 2019.)

Davids, Y.D., L. Verwey, A. Bhagat \& G. Onuoha 2016. Community Advice Offices: Taking Charge in Marginalised Communities. In Plaatjies, D., M. Chitiga-Mabugu, C. Hongoro, T. Meyiwa, M. Nkondo \& F. Nyamnjoh (eds): State of the Nation South Africa 2016: Who is in Charge? Mandates, Accountability and Contestations in the South African State. Cape Town: HSRC Press.

Dei, G. 2012. Indigenous Anti-Colonial Knowledge as 'Heritage Knowledge' for Promoting Black/ African Education in Diasporic Contexts.

Decolonization: Indigeneity, Education \& Society 1,1:102 - 119.

Dlamini v Joosten ([2005] JOL 16179 (SCA)). 
Dugard, J. \& K. Drage 2013. To Whom do the People Take Their Issues? The Contribution of Community-Based Paralegals to Access to Justice in South Africa. Socio-economic Rights Institutes of South Africa. Justice and Development, Working Paper Series, 21/2013. Johannesburg: World Bank. Available at: https://52.21.52.208/handle/10986/16597

(Accessed on 10 October 2018.)

Edwards, H.T. 1986. Alternative Dispute Resolution: Panacea or Anathema? Harvard Law Review 99,3: 668 - 684.

https://doi.org/10.2307/1341152

Gilbert, J. 2017. Litigating Indigenous Peoples' Rights in Africa: Potentials,

Challenges and Limitations. International and Comparative Law Quarterly 66: 657 - 686.

https://doi.org/10.1017/S0020589317000203

Grosfoguel, R. 2013. The Structure of Knowledge in Westernized Universities: Epistemic Racism/ Sexism and the Four Genocides/ Epistemicides of the Long 16th Century. Human Architecture: Journal of the Sociology of SelfKnowledge 11,1: 73 - 90.

Hamoudi, H.A. 2014. Decolonizing the Centralist Mind: Legal Pluralism and the Rule of Law. In Marshall, D. (ed.): The International Rule of Law Movement: A Crisis of Legitimacy and the Way Forward. Cambridge, MA: Harvard University Press.

Hensler, D.R. 2003. Our Courts, Ourselves: How the Alternative Dispute Resolution Movement is Re-Shaping Our Legal system. Penn State Law Review 108:165-183.

Himonga, C.A \& F. Diallo 2017. Decolonisation and Teaching Law in Africa

with Special Reference to Living Customary Law. Potchefstroom Electronic Law Journal/ Potchefstroomse Elektroniese Regsblad 20: 1 19. https://doi.org/10.17159/1727-3781/2017/v20i0a3267

Krever, T. 2011. The Legal Turn in Late Development Theory: The Rule of

Law and the World Bank's Development Model. Harvard International Law Journal 52,1: 288 - 319.

Lopes Cardozo, M.T.A. \& J. Strauss 2012. From the Local to the Regional and Back: Bolivia's Politics of Decolonizing Education in the Context of ALBA. In Muhr, T. (ed.): Resistance to Global Capitalism: ALBA and the Bolivarian Revolution in Latin America and the Caribbean. (Rethinking Globalizations Series.) Abingdon-on-Thames: Routledge. Mabena v Letsoalo ([1998] 2 SA 1068 (T)). 
Macdonald, R.A., \& T.B. McMorrow 2013. Decolonizing Law School. Alberta Law Review 51,4: 717.

https://doi.org/10.29173/alr34

Madlingozi, T. 2010. On Transitional Justice Entrepreneurs and the Production of Victims. Journal of Human Rights Practice 2,2: 2010.

https://doi.org/10.1093/jhuman/huq005

Martins, W. 2016. Access to Justice: The Role of Community-Based Paralegals in Community Restorative Justice in Rural Kwazulu-Natal. Unpublished Doctoral Thesis. University of KwaZulu-Natal.

Maru, V. \& V. Gauri (eds.). 2018. Community Paralegals and the Pursuit of Justice. Cambridge: Cambridge University Press.

https://doi.org/10.1017/9781316671801

Masolo, D.A. 2012. Care Versus Justice: Odera Oruka and the Quest for Global Justice. Thought and Practice: Journal of the Philosophical Association of Kenya 4,2: 23 - 49.

McDougal, S. 2014. Africana Studies' Epistemic Identity: An Analysis of Theory and Epistemology in the Discipline. Journal of African American Studies 18: 236 - 250.

https://doi.org/10.1007/s12111-013-9265-2

McLaughlin, J.M. \& S.L. Whatman 2008. Embedding University Perspectives in University Teaching and Learning: Lessons Learnt and Possibilities for Reforming/ Decolonising Curriculum. In Heber, R.W. (ed.): Indigenous Education: Asia/Pacific. Regina, Saskatchewan: Indigenous Studies Research Centre, First Nations University of Canada.

Menkel-Meadow, C.J., L. Porter-Love, A. Kupfer-Schneider \& M. Moffitt 2018. Dispute Resolution: Beyond the Adversarial Model. New York: Aspen Publishers.

Modiri, J.M. 2016. The Time and Space of Critical Legal Pedagogy. Stellenbosch Law Review 27: 507 - 534.

Modiri, J.M. 2018. Conquest and Constitutionalism: First Thoughts on an Alternative Jurisprudence. South African Journal on Human Rights. Available at: DOI: 10.1080/02587203.2018.1550939 (Accessed on 20 August 2019.) https://doi.org/10.1080/02587203.2018.1550939

Maldonado-Torres, N. 2011. Thinking through the Decolonial Turn: PostContinental Interventions in Theory, Philosophy, and Critique - An Introduction. Transmodernity: Journal of Peripheral Culture Production of the Luso-Hispanic World 1,2: 1 - 15. 
Merry, S.E. 1988. Legal Pluralism, Journal of Law \& Society 20: 869 - 896. https://doi.org/10.2307/3053638

Mungwini, P. 2013. African Modernities and the Critical Reappropriation of Indigenous Knowledges: Towards a Polycentric Global Epistemology. International Journal of African Renaissance Studies - Multi-, Inter-and Transdisciplinarity 8,1: 78 - 93.

https://doi.org/10.1080/18186874.2013.834556

Nabudere D.W. 2011. Afrikology, Philosophy and Wholeness: An Epistemology. Pretoria: Africa Institute of South Africa.

Nakata, M. 2007. The Cultural Interface. The Australian Journal of Indigenous Higher Education 36,Supplement: 7 - 14.

https://doi.org/10.1017/S1326011100004646

Ndima, D. 2003. The African Law of the $21^{\text {st }}$ Century in South Africa. The Comparative and International Law Journal of Southern Africa 36,3: 225 -345 .

Ndulo, M. 2011. African Customary Law, Customs and Women's Rights. Indiana Journal of Global Studies Legal Studies 18,1: 87 - 120.

https://doi.org/10.2979/indjglolegstu.18.1.87

Nkabinde v Road Accident Fund ([2001] 3 All SA 611 (W)).

Nkosi v Bührmann ([2002] 1 SA 372 (SCA)).

Ntlama, N. 2009. 'Equality' Misplaced in the Development of the Customary Law of Succession: Lessons from Shilubana v Nwamitwa 20092 SA 66 (CC). Stellenbosch Law Review 20: 333 - 356.

https://doi.org/10.1080/18186870903101974

Ntlama, N. \& D. Ndima 2009. The Significance of South Africa's Traditional Courts Bill to the Challenge of Promoting African Traditional Justice Systems. International Journal of African Renaissance Studies 4,1: 6 - 30. Ndlovu-Gatsheni, S.J. 2018. The Dynamics of Epistemological Decolonisation in the $21^{\text {st }}$ Century: Towards Epistemic Freedom. Strategic Review for Southern Africa 40,1: 16 - 45.

Paetsch J., L. Bertrand \& J.P Boyd 2018. An Evaluation of the Cost of Family Law Disputes: Measuring the Cost Implication of Various Dispute Resolution Methods. Canadian Forum on Civil Justice. Available at: http://www.cfcj-fcjc.org/sites/default/files//docs/Cost-Implication-of FamilyLawDisputes.pdf. (Accessed on 03 March 2018.)

Pimentel, D. 2011. Legal Pluralism in Post-Colonial Africa: Linking Statutory and Customary Adjudication in Mozambique. Yale Human Rights and 
Fayth Ruffin

Development Journal 14,1: 59 - 104.

https://doi.org/10.2139/ssrn.1668063

Ramoitheki v Liberty Group Ltd t/a Liberty Corporate Benefits ([2006] JOL $18075(\mathrm{~W}))$.

Republic of South Africa. 1996. Constitution of the Republic of South Africa.

Pretoria: Government Printer.

Republic of South Africa. 2004. Indigenous Knowledge Policy. Pretoria:

Government Printer.

Republic of South Africa. 2019. Indigenous Knowledge Act 6 of 2019. Pretoria:

Government Printer.

Roberts, S. 1998. Against Legal Pluralism: Some Reflections on the Contemporary Enlargement of the Legal Domain. Journal of Legal

Pluralism and Unofficial Law 42: 95 - 106.

https://doi.org/10.1080/07329113.1998.10756517

Ruffin, F. 2009. Continuity and Change: Moral Considerations of Grotius in International Law and Global Politics - Historically, Contemporarily \& Futuristically. International Studies Association 2009 Annual Convention, 15-18 February. New York.

Ruffin, F. \& W. Martins 2016. Legal Empowerment as Social Entrepreneurship: The Kwazulu-Natal Cases of Bulwer and New Hanover. In Fields, Z. (ed.): Incorporating Business Models and Strategies into Social Entrepreneurship. Hershey, PA: IGI Global.

https://doi.org/10.4018/978-1-4666-8748-6.ch015

Ruffin, F. 2018. Land Governance in the Context of Legal Pluralism: Cases of Ghana and Kenya. In Akinola, A.O. and H. Wissink (eds): Trajectory of Land Reform in Post-Colonial African States: The Quest for Sustainable Development and Utilization. Cham, Switzerland: Springer. https://doi.org/10.1007/978-3-319-78701-5 7

Ruffin, F. 2019. Exploring Case Management Strategies for the Community Advice Office Sector: The Centre for Community Justice and Development and Fifteen Community Advice Offices 2014 to 2017. Research Report on Project Funded by Open Society Justice Institute. Pietermaritzburg: Centre for Community Justice and Development.

Ruffin, F., L.J. Teffo \& H. Kaya 2016. African Indigenous Languages and Environmental Communication. Journal of Human Ecology 53,2: 185 193.

https://doi.org/10.1080/09709274.2016.11906971 
Sandoval, D., R. Lagunas, L. Montelongo \& M. Díaz 2016. Ancestral Knowledge Systems: A Conceptual Framework for Decolonizing Research in Social Science. Alter/Native 12,1: 18 - 31.

https://doi.org/10.20507/AlterNative.2016.12.1.2

Shilubana v. Nwamitwa ([2009] 2 SA (CC)).

Skelton, A. 2011. Regional Reviews. In Johnston, G. \& D. Van Ness, D. (eds): Handbook of Restorative Justice. London: Routledge.

Tamanaha, B.Z. 2008. Understanding Legal Pluralism: Past to Present, Local to Global. Sydney Law Review 30: 375 - 411.

Teffo, L. 2011. Epistemic Pluralism for Knowledge Transformation. International Journal of African Renaissance Studies - Multi-, Inter-, and Transdisciplinarity 6,11: 24 - 34.

https://doi.org/10.1080/18186874.2011.592388

Tuck, E. \& K.W. Yang 2012. Decolonization is Not a Metaphor. Decolonization: Indigeneity, Education \& Society 1,1: 1 - 40.

United Nations. 2007. Declaration on the Rights of Indigenous Peoples. Available at:

http://www.un.org/esa/socdev/unpfii/documents/DRIPS en.pdf (Accessed on 02 February 2019.)

Twining, W. 2010. Normative and Legal Pluralism: A Global Perspective. The Seventh Annual Herbert L. Bernstein Memorial Lecture in International and Comparative Law, Duke University School of Law, 7 April 2009. Available at:

http://scholarship.law.duke.edu/cgi/viewcontent.cgi?article $=1049 \&$ conte $\mathrm{xt}=$ djcil.

(Accessed on 22 October 2018.)

Van Dijk, T. 1997. The Study of Discourse. In Van Dijk, T. (ed.): Discourse as Structure and Process. Discourse Studies 1. London: Sage Publishers. https://doi.org/10.4135/9781446221884.n1

Wa Thiong'o, N. 2009. Something Torn and New: An African Renaissance. New York: Basic Civitas Books.

Wojkowska, E. 2006. Doing Justice: How Informal Justice Systems can Contribute. Oslo: United Nations Development Programme.

Wolfe, P. 1999. Settler Colonialism. London: A\&C Black.

Williams, C. 1974. The Destruction of Black Civilization: Great Issues of a Race from 4500 B.C. to 2000 A.D. Chicago, Illinois: Third World Press. https://doi.org/10.1080/19962126.2013.11865075 
Fayth Ruffin

Williams, J. \& J. Klusener 2013. The Traditional Courts Bill: A Woman's Perspective. South African Journal of Human Rights 29: 276 - 293.

Yanow, D. \& P. Schwartz-Shea (eds.). 2015. Interpretation and Method:

Empirical Research Methods and the Interpretive Turn. $2^{\text {nd }}$ Edition. New York: Routledge.

https://doi.org/10.4324/9781315703275

Zhang Y. \& B. Wildemuth 2009. Qualitative Analysis of Content. In

Wildemuth, B. (ed.): Applications of Social Research Methods to Questions in Information and Library Science. Westport, CT: Libraries Unlimited.

Fayth Ruffin

School of Management, IT \& Governance College of Law and Management Studies University of KwaZulu-Natal ruffin@ukzn.ac.za 